\title{
Representations of Intellectuals in Changing Places: A Tale of Two Campuses (1975): An Existentialist View ${ }^{\mathrm{a}}$
}

\author{
İbrahim Kâtip ${ }^{\mathrm{b}, \mathrm{c}}$, Aylin Atilla d
}

\section{Abstract}

This study analyzes the characters of David Lodge's novel, Changing Places: A Tale of Two Campuses in the light of the philosophy of Existentialism. As Sartre has argued, the existence of a person comes before his essence. A person interprets this existence through external factors. Stripped of these factors, his/her existence constitutes his essence. Yet, the way of dealing with the external factors like social roles constitute his/her real essence. Hence, when stuck between these two essences, a person is likely to experience existential crisis. The characters who reflect these crises mostly appear in the novels written after 1950. With this study, the existential crises of the protagonists, their quests for identity and purpose as intellectuals are analyzed, and the novel, which was generally analyzed in terms of its parodical elements formerly, is reread with a different view. This analysis also sheds light on the situation of today's academic world.
Keywords

The Campus Novel

Existentialism

Intellectuality

David Lodge

About Article

Geliş Tarihi: 28.06.2021

Kabul Tarihi: 24.09.2021

Doi: $10.18026 /$ cbayarsos. 958427

\section{Changing Places: A Tale of Two Campuses (1975) Romanında Entelektüellerin Temsilleri: Varoluşçu Bir Bakış}

\section{Özet}

$\mathrm{Bu}$ çalışmada Varoluşçu felsefenin ilkeleri kullanılarak David Lodge'ın Changing Places: A Tale of Two Campuses eseri üzerinde metin ve karakter analizi yapılmıştır. Fransız filozof Jean Paul Sartre'ın belirttiği üzere bir insanın varoluşu onun özünden önce gelir. İnsan bu varoluşunu, toplumdaki yerini ve işlevini dış etmenler üzerinden anlamlandırır. Sartre'a göre, bu etmenler olmaksızın bireyin varoluşu onun özünü oluşturur. Toplumsal roller, edinimler ve yerleşik davranış kalıpları gibi dışa bağlı etkenlere karşı bireyin tepkisi ve izlediği yol ise birey için gerçek özü oluşturur. Bu bağlamda, bireyin öz ve gerçek öz arasında sıkışması varoluşsal krizlere yol açabilir. Özellikle 1950 sonrası yazılan romanlarda, bireyin varoluşsal bunalımlarını farklı şekillerde yansıtan karakterlere sıkça rastlanmaktadır. Bu çalışma ile baş karakterlerin varoluşsal bunalımları, birer entelektüel olarak kimlik, anlam ve amaç arayışları incelenmekte ve daha önceleri genelde parodi unsurları üzerinden incelenen bu eser farklı bir pencereden okunmaktadır. Kurgusal düzlemde yapılan bu inceleme günümüz akademik dünyasının mevcut durumuna da ışık tutmaktadır.
Anahtar Kelimeler

Kampüs romanı

Varoluşçuluk

Entelektüellik

David Lodge

Makale Hakkında

Received: 28.06.2021

Accepted: 24.09.2021

Doi: $10.18026 /$ cbayarsos. 958427

\footnotetext{
a This essay is produced from İbrahim Katip's PhD Dissertation.

b Contact Author: ibrahim.katip@cbu.edu.tr

c Res. Assist. Dr., Manisa Celal Bayar University/ Faculty of Science and Letters, Department of English Language and Literature, Manisa/ TURKEY ORCID: 0000-0002-9658-6899

d Assoc. Prof. Dr, Ege University/ Faculty of Letters, Department of English Language and Literature, Izmir/ TURKEY ORCID: 0000-0002-0348-4763
} 


\section{Introduction}

The aim of this study is to analyze David Lodge's novel, Changing Places: A Tale of Two Campuses (1975), in the light of the principles of the philosophy of Existentialism. Jean Paul Sartre (1965), the French philosopher, has argued that the existence of a person comes before his essence. Still, a person interprets this existence, his place and function within a society through external factors. Without these factors, according to Sartre, the existence of an individual constitutes his essence. The reaction and the way of dealing with the external factors like social roles, acquisitions, behavioral patterns or codes of behaviors in certain situations, on the other hand, constitute the real essence for the individual. Again, Sartre (1943/1978) himself asserts that it is pointless for one to lament or complain about himself/herself because what one feels, what one experiences or becomes is his/her own choice. In this respect, when stuck between the essence and the real essence, a person is likely to experience existential crisis. This paper aims to find out these existential crises experienced by the characters in the novel and the ways they cope with them, using the principles of the philosophy of Existentialism.

As the protagonists of the novel are urban intellectuals of the contemporary society who are university professors, this essay also aims to determine the intellectual features of these main characters by using the standards set forward by writers and philosophers like Antonio Gramsci, Edward Said, Michel Foucault and Jean Paul Sartre. In this respect, the different aspects of the intellectuality of these university professors are discussed and their functionality in the humanities departments is revealed.

\section{Intellectuals on a Quest: An Academic Journey of Self-Discovery}

Changing Places tells the story of two English Literature scholars, Philip Swallow from Britain and Morris Zapp from the United States, who change their places for six months in accordance with a faculty exchange program between their universities. Philip is described as a cold and stiff character who lacks self-esteem, and who seems to be at a loss between his academic endeavours and personal marriage struggles. Morris Zapp, on the other hand, is described as a confident, relaxed and an experienced academic who is also very successful and well-known for his academic works as well as his unapologetic and straightforward nature. As these two opposite intellectual characters, Swallow from the University of Rummidge and Zapp from the University of Euphoria, change places, the storyline moves from one country to another perpetually and the differences in higher education systems of both countries are also revealed. As Falk and Molloy (1985) state; "David Lodge, in Changing Places (1975), tells the story of college professors, one an American and the other British. The two main characters, through default rather than design, 'change places.' Each learns much from his exchange that could never have been anticipated in advance" (p. 379). It may be true that they learn a lot from this experience but does it help them to solve their personal problems? To answer this question a close look at the personal lives of the characters will be helpful.

Zapp was only forty years old when he accomplished almost everything required in his area of study. So, he is, like Swallow, also at a loss, but about finding more to achieve or to do as explained in the book as:

Zapp was the man who published articles in PMLA while still in graduate school; who, enviably offered his first job by Euphoric State, had stuck out for twice the going 
salary, and got it; who had published five fiendishly clever books (four of them on Jane Austen) by the time he was thirty and achieved the rank of full professor at the same precocious age. (Lodge, 1975/1978, p. 15)

The one exception to his constant achievements, as Anténe (2015) observes, was when he could not finish a crazy plan, a struggle to study all the novels of Jane Austen "from every conceivable angle, historical, biographical, rhetorical, mythical, Freudian, Jungian, existentialist ... so that when each commentary was written there would be simply nothing further to say about the novel in question" (Lodge, 1975/1978, p. 44). Obviously, before he could finish Sense and Sensibility, Zapp comprehends that such a mission is not achievable (Anténe, 2015). Still, this shows how competitive and obsessive Zapp is and explains the motive behind his other actions in the novel.

The swift progress of Zapp's career has a less wanted equivalent in his stormy private life. Having already been married twice, Zapp has also had numerous illicit love affairs. Undeniably, Anténe argues, Zapp's sudden conclusion to join the Rummidge exchange program is driven by the expectation to delay or avoid his second divorce. Zapp has a daughter named Melanie from his first marriage, who is now a student at the University of Euphoria. Yet, Melanie disconnects herself from her father by using her mother's original surname, Byrd. Zapp also has nine-year-old twins named Elizabeth and Darcy with his second wife, Désirée. The twins are named after the characters of Jane Austen's Pride and Prejudice. For Zapp, nevertheless, there is almost no hope that Désirée will abandon her decision about divorcing him (Anténe, 2015). As a sign of Désirée's solid decision, she complains about their marriage by saying: "Being married to you is like being slowly swallowed by a python. I'm just a half-digested bulge in your ego" (Lodge, 1975/1978, p. 40). Hence, Zapp's travel to the University of Rummidge as an exchange scholar can be interpreted as a kind of escape from his problematic marriage and disturbed psychology.

As the subtitle of the novel is A Tale of Two Campuses, with a reference to Charles Dickens' $A$ Tale of Two Cities (1859), the locales of the two university campuses are also significant. The University of Euphoria is located in the State of California, which is called as "Euphoric State" in the novel and the governor of Euphoric State is Ronald Duck, as Lodge changes the name of the real governor at the time who was Ronald Reagan. The American university is described as beautiful with scenic surroundings and warm climate, offering many facilities to its faculty and students. The University of Rummidge, on the other hand, is dull, cold and raw, situated in a city like Birmingham, an industrial area of England. Thus, the two characters do not only exchange their academic positions, but they also travel to cities with exact opposite characteristics.

The two opposite characters of the same profession, Zapp and Swallow, reveal how different is the academic perceived in different countries. Morris Zapp is a distinguished academic who has published in highly esteemed journals like PMLA. He also has published five books, four of which are on Jane Austen's works. Philip Swallow, on the other hand, has a few articles and reviews in insignificant journals, not a single book or $\mathrm{PhD}$ dissertation although he is a strict instructor who carefully examines every exam paper for grammar mistakes. He has cleverness and capacity but lacks determination and desire. In Lodge's words he lacks: "the professional killer instinct" (Lodge, 1975/1978, p. 15). Here is a description of a young British scholar from the novel: 
The British postgraduate student is a lonely, forlorn soul, uncertain of what he is doing or whom he is trying to please- you may recognize him in the tea-shops around the Bodleian and the British Museum by the glazed look in his eyes, the vacant stare of the shell-shocked veteran for whom nothing has been real since the Big Push. As long as he manages to land his first job, this is no handicap in the short run, since tenure is virtually automatic in British universities, and everyone is paid on the same scale. But at a certain age, the age at which promotions and Chairs begin to occupy a man's thoughts, he may look back with wistful nostalgia to the days when his wits ran fresh and clear, directed to a single, positive goal. (Lodge, 1975/1978, p. 16)

This passive picture of the British young scholar is in contrast with his American colleagues. As Anténe (2015) argues, in Changing Places, research and teaching are both depicted as vital for academic profession. At the University of Euphoria, publishing in academic journals is the most important factor for getting tenure. Moreover, as the students make their voices heard more and more, their assessments of their professors in Class Bulletin are also taken into consideration in academic progress of the faculty. Even though the English Department at Euphoria is described nearly as big as the whole faculty of arts at Rummidge, Anténe (2015) states, the university is "buying" (Lodge, 1975/1978, p. 13) only the most eminent professors and it is extremely competitive there to make a career. As Swallow writes it in a letter to Hilary, the necessities for tenure at Euphoria remind him of "a jungle in which the weakest go to the wall" (Lodge, 1975/1978, p. 133). Paradoxically, Swallow is ignorant of the fact that he has been sent overseas in order to promote one of his younger colleagues, who has written many academic essays, during Philip's absence in spite of Rummidge's principle of seniority. Thus, while seniority and experience seem to be the dominant factors in academic promotions in Britain, publishing essays and books appears to be more important in terms of promotions in American universities.

Although Lodge seems to be criticizing the British higher education system in some respects, he was also criticized by others for the way he represented the university and life of scholars. Michael Shattock (1984) supports the idea that there was a real public discontent with the performance of higher education and that British education system and intellectuals had excluded the industrial ideals of the early Victorian period, becoming a burden on the services of financial growth. The portrayal of higher education, he argues:

in novels like The History Man, Changing Places or Educating Rita served only to confirm this, while the image of rebellious students, alternative life styles and high livinghowever atypical of the norms of life in higher education, did nothing to reassure the public that its tax contributions were being well spent. (Shattock, 1984, p. 202)

During a historical era of increasing financial decline, he suggests, the occupants of the higher education community were less and less supported by the public in general and this in turn made the academy more defenseless to exploitations regarding the budgets provided by government (Shattock, 1984). So, authors of the campus novels were also blamed, at least partly and from time to time, for the role they played in the weak representations of the academic life in campus novels.

Another important aspect of Changing Places is that it presents the elements of metafiction into the campus novel for the first time. As Anténe (2015) suggests, the reader witnesses one of the cleverest metafictional passages in the novel in the third chapter which completely 
consists of letters exchanged between the two professors and their wives. This feature provides the reader with an entree to the opinions and feelings of all the four characters. After Swallow has been selected to teach Creative writing course at the University of Euphoria, he asks Hilary, his wife, to send him a book called Let's Write a Novel from his library in Rummidge. In a reply letter to Philip, Hilary writes: "What a funny little book it is. There's a whole chapter on how to write an epistolary novel, but surely nobody's done that since the eighteenth century?" (Lodge, 1975/1978, p. 130). In fact, Lodge just has written one. Yet, Lodge, in Changing Places, is not content with the rebirth of the epistolary novel, as the fourth chapter is written in the form of newspaper articles and the last one is written in the form of a screenplay. Although this variety in writing technique was innovative in Changing Places, Anténe (2015) argues, "unfortunately, the author later repeated most of these innovatory techniques in his later campus fiction, from Small World to Deaf Sentence, making them almost a cliché inventory of a Lodge novel" (p. 85). Thus, Lodge was also criticized for his overuse of different techniques beside his representation of academic characters and life.

It is a known fact, as acknowledged by Lodge himself, that the author derives his fictional characters, at least partly, from his real-life experiences. Like Bradbury, he also likens his academic travels to pilgrimages which include personal transformations beside academic achievements (Lodge, 1996). J. Russel Perkin (2008), in his essay called "The Pilgrimages of David Lodge" asserts that the several forms of pilgrimage in modern-day society have been a frequent focus in the novels of David Lodge, who is both a Roman Catholic and a deep viewer of postmodern culture. In his essay, he traces Lodge's use of the theme of pilgrimage, from his demonstration of old Catholic sacred expeditions in some of his novels to much more symbolic extensions of the notion of religious travel. He believes that travel and pilgrimage play a significant role in Lodge's fiction and that Lodge emphasizes "the liberating effect of travel, and like many writers - notably Henry James, with whom he has an important intertextual relationship - he often uses a journey to represent a metaphorical journey within the self" (p. 420). He underlines the importance of travel in Lodge's Changing Places, in particular, in his following words:

while Changing Places represents a sojourn an experience of self-transformation ... in the essay "The Bowling Alley and the Sun" he describes the liberating effect of a visit to the United States, an experience that formed the basis of his novel Changing Places. Travel plays a prominent role in most of Lodge's novels. (Perkin, 2008, p. 424)

Moreover, as Lodge employs themes of travel and self-transformation, it must also be kept in mind that the concept of travel for the travelling academics in the novel also differs in meaning and effect. As Falk and Molloy (1985) suggest, a usual British student may travel minor distances, when compared to his American counterparts, but the arrival points are mostly located in different areas culturally. "The 1.5-hour drive from London to Birmingham", they state, "takes one from the lush middle-class pastures of the Southeast to the heart of the industrial Midlands (the locale of David Lodge's mythical university in Changing Places)" (p. 387). Thus, Falk and Molloy (1985) argue that although the United States is a geographically vast country, cultural variety is much more visible in Britain. This may be the reason why Philip Swallow blends in with the American life easier than Morris Zapp, who has a relatively hard time adjusting to the social and academic life in Rummidge.

If Lodge employs his own academic travels in creating his fiction, then who are the origins of Morris Zapp and Philip Swallow in real life? In "Pretending to Be Real: Stephen Greenblatt 
and the Legacy of Popular Existentialism", Paul Stevens (2002) states that in his 1990 collection of essays Learning to Curse, Greenblatt looks back with significant nostalgia on the days of deep-seated excitement when he first arrived at Berkeley in 1969, and calls it:

a time when National Guard troops and heavily armed squadrons of police battled massive student and faculty protests against the Viet Nam War; the campus was redolent of tear gas. Everything was in an uproar ... It was, in its way, sublime. (Greenblatt, as cited in Stevens, 2002, p. 493)

He argues that David Lodge's 1975 novel, Changing Places reminisces precisely the same period in the English department at Berkeley, California, as Philip Swallow gets involved in student marches and protests. Moreover, Stanley Fish, a famous American scholar from Berkeley, appears in the novel, Stevens (2002) argues, as Morris Zapp, and so do Greenblatt and his former wife Ellen would seem to appear as Sy Gootblatt and his wife Bella in the novel. Thus, if what Stevens suggests is true, Lodge might be said to present a very realistic portrayal of academic life in Changing Places. In this sense, what can be said about Philip Swallow? The most probable guess, no doubt, would be the author himself, David Lodge.

Throughout their exchange period, Zapp and Swallow sleep with each other's wives. When their affairs are revealed to each party, towards the end of the semester, they decide to meet at a hotel in New York to discuss the situation and find a mutual solution. According to Anténe (2015), although the novel is open-ended, as in the final chapter where the four main characters meet in New York to resolve the state of affairs and the novel ends, leaving their dialogue unfinished, the reader can simply presume what the conclusion will be. Despite his appeal to Désirée and America, Swallow confesses to her before that he will go "back to Hilary and the children. Back to Rummidge. Back to England" (Lodge, 1975/1978, p. 176). Désirée also declares to Swallow that although she wants to get divorced, she has no aim of getting married again, as she is happy to be a "free woman" (Lodge, 1975/1978, p. 175). So, as foreshadowed by their previous dialogues, and as Lodge later discloses in Small World (1984), the sequel to Changing Places, Swallow returns to Hilary and Zapp does not achieve to evade his divorce from Désirée.

Hence, for all its twists and turns, comic or serious, Anténe (2015) suggests, the plot of Changing Places finally arrive to a very parallel state of events as they are defined at the opening. Despite its outward lack of closure, he argues, "Changing Places provides enough hints that the text tends towards the restorative ending reminiscent of the comic literary tradition" (p. 79). When considered by itself, what Anténe comments on the ending may be true. However, as there is a sequel, the total ending of the plot, would provide a better understanding whether there is a restorative ending or not. Moreover, returning to their wives or homelands does not necessarily mean that they returned to their initial states as neither Zapp nor Swallow is the same person he was at the beginning of the novel. The same goes for their wives, Désirée and Hilary as well.

On the other hand, it would be wrong to see Swallow as a completely changed, a radical character. His instinct of the fear of the other, and his prejudice for different people can be exemplified by his encounters with one of his students in Euphoria. The name of this student is Black Smith. The surname Smith itself, according to Friji (2019), reminds us the workingclass profession of blacksmith. The fact that Smith persists he is black even though he is not, also increases the reliability of this estimation. A name like Black Smith, one may infer, 
would be of immense implication in that it brings together racial and working-class characteristics and, by so doing, "it subverts not only conventional names but also the positive characteristics associated with them" (Friji, 2019, p. 29). So, this comment implies that Swallow still has a stereotypical view of people although he is trying to make progress as an academic and a liberal person.

Besides, this is consistent with Smith's total dislike of traditional courses and educational rules. When Swallow first meets him, it is noteworthy that he is wearing "some kind of army combat jacket with camouflage markings" (Lodge, 1975/1978, p. 65). When he puts his hand in his pocket, Swallow worries that he will take out a bomb, but he is relieved when it turns out to be just a list of courses. Smith's approval of aggressive strategies, Friji (2019) states, "finds its best expression in the fact that when Swallow allows him to enroll in his creative writing course, he urges his fellow students to boycott not only this course but also other classes, by way of supporting the strike" (p. 29). What one understands from these comments is that Swallow is rather defensive and elusive when faced with young and revolutionary people like Smith.

Furthermore, Friji (2019) suggests, it is hard for Swallow "to swallow rebelliousness" (p. 32). The transformation he experiences towards the end of the novel contradicts with his wife's view that he looks as if he has turned into "one of these violent snobs, who think that nothing's important unless people are getting killed" (Lodge, 1975/1978, p. 247). Observing the Plotinus March on TV, the name of the students protests in Euphoria, Swallow starts an enthusiastic argument for liberal humanistic ethics. He insists that he would not prefer to side with the marchers because "that is no country for old men'" (p. 249) and because he would only "be an imposter there" (p. 249). His generation, he believes, "subscribe to the old liberal doctrine of inviolate self" (p. 250) as embodied by the realistic novels of Jane Austen, which underline the importance of private life while downgrading history to the background and seeing it only as "a distant rumble of gunfire, somewhere offstage" (p. 250). So, Swallow, at the end of the novel, realizes the generation gap between his generation and the new generation in terms of the comprehension of history, which he suggests is outdated and wrong.

Swallow's desertion of his revolutionary passion takes place when he, Hilary, Zapp and his wife, Désirée are having a meeting in New York to solve their marital problems. As the novel does not propose any open hint to the result of their discussion, Friji (2019) asserts, one can just presume that they will return to their marriage, at least the Swallows, and start again. In fact, Lodge reveals that, despite their ups and downs, the two couples are still in similar conditions in the sequel to his Changing Places. Thus, in accordance with Anténe's and Friji's comments, it can be said that even though Swallow pursues a new life and break his chains, both in his private and professional life, in the end, he does not feel powerful enough to do so and returns to his old, safe and stable condition.

Morris Zapp, on the other hand, as Barbara Arizti Martin (2000) asserts, for his successful involvement in the student protest at Rummidge University, which signals a message of calm and "effective collaborationism with the system" (p. 299), can be seen as an embodiment of the neoconservative ideology. Swallow's course of change, she suggests, contains a risky but temporary countercultural step in which he recognizes the fight of the young generation against the tyranny of society. Philip's expedition, still, ends in a private zone where individual power is allowed, and which fixes people in a contented existence 
deprived of any public worries. Changing Places, according to Martin (2000), "gives priority to integration in society over a dangerous questioning of the status quo. It demonstrates a general lack of interest in social change and privileges the private over the public" (p. 299). Martin shares the views of Anténe and Friji and she also blames the author for creating characters that are the embodiments of neoconservative approach. Although, one can see where she is coming from, it wouldn't do justice to call these middle-aged and confused men as neoconservatists as they actually try to understand and help the so-called revolutionary students, who are yet so young and inexperienced.

Furthermore, Martin (2000) argues that, Philip Swallow exemplifies an effort at distorting and modifying the ideological dispute mirrored in the novel when he is trapped between the countercultural actions described in Changing Places and the undoubtedly neoconservative attitude of Morris Zapp. With Philip's progress in the direction of postmodernity, she suggests, David Lodge seems to be ignoring the ideological questions. She concludes, "in Swallow's withdrawal to the private sphere Lodge is once again showing his conservative bias. Swallow's postmodern attitude is a veiled form of conservatism" (p. 301). Hence, Martin, by blaming the two academic characters, and the author, for being conservatives who are turning a blind eye to social problems, also makes their intellectual value open to question. Therefore, it would be convenient now to discuss the intellectual features of these characters.

Regarding the roles and the function of the intellectual, Italian philosopher and politician, Antonio Gramsci (1947/1992), in his Prison Notebooks, states that "all men are intellectuals, one could therefore say: but not all men have in society the function of intellectuals" (p. 9). This may sound puzzling at first but he explains his definition with further examples. What he wants to demonstrate is that people who actually execute the task of intellectual in society, can be divided into two categories. The first of these is the traditional intellectuals, for instance, instructors, ministers, or bureaucrats, who carry on doing the similar thing from generation to generation. The second category is the organic intellectuals, who are, according to Gramsci, closely linked to classes or enterprises that used intellectuals to establish interests and achieve more power in order to have more control. Accordingly, Gramsci (1947/1992) defines the organic intellectual as "the capitalist entrepreneur creates alongside himself the industrial technician, the specialist in political economy, the organizers of a new culture, of a new legal system, etc." (p. 5). Whether the professor or the graduate student falls into one of these categories of Gramsci or not is debatable. In this sense, one tends to think of them, especially the scholars in the humanities departments as traditional intellectuals, at least principally.

According to Gramsci (1947/1992), organic intellectuals are enthusiastically involved in society, in that they persistently fight to alter thoughts and expand their audience. They are constantly on the road, trying to affect people. Whereas professors and clerics, the traditional intellectuals, appear relatively lingering in their place, performing almost the identical type of work each year (p. 8). One can see that Gramsci's social study of the intellectual as a person who accomplishes a specific set of functions in the society is considerably close to the reality of the world today, in the late twentieth century or early twenty-first century when so many new professions like newscasters, academics, computer experts, administration advisors, policy experts, government advisers, and the entire field of modern journalism have justified Gramsci's vision. Today, anyone who works in any field connected either with 
the production or circulation of knowledge can be considered an intellectual in Gramsci's sense.

In an interview, Michel Foucault (1980), the French philosopher, has made a similar comment in terms of intellectuality. Foucault has argued that the supposed universal intellectual has had his or her place taken by the "specific" intellectual (pp. 127-8). Here, Foucault's universal intellectual can be seen as Gramsci's traditional intellectual, and specific intellectual can be considered as, again, Gramsci's organic intellectual. Thus, one can derive from these comments that class and social function is important in the categorization and definition of intellectuality and intellectuals.

In this respect, it would be useful to refer to Edward W. Said's (1994/1996) opinions about the subject. In his book, Representations of the Intellectual, Said argues that different histories and sociologies of intellectuals are present in the society in numerous variations. Also, one can witness "endless accounts of intellectuals and nationalism, and power, and tradition, and revolution, and on and on" (p. 10). According to Said, the main objective of an intellectual should be "representing, embodying, articulating a message, a view, an attitude, philosophy or opinion to, as well as for, a public" (p. 11). He does not believe that it is possible to be a "private intellectual", as the moment one writes down words and then publishes them one enters the public sphere. He argues that intellectuals are "individuals with a vocation for the art of representing, whether that is talking, writing teaching, appearing on television" (pp. 12-3). Thus, Said stresses the public responsibility of the intellectuals regardless of their personal aims and puts a social burden on the shoulders of intellectuals.

Moreover, Said (1994/1996) sees Gramsci's category of the organic intellectual as a threat to intellectuality. The actual threat to the intellectual today, whether in the West or the nonWestern world, he says:

is not the academy, nor the suburbs, nor the appalling commercialism of journalism and publishing houses, but rather an attitude that I will call professionalism. By professionalism I mean thinking of your work as an intellectual as something you do for a living, between the hours of nine and five with one eye on the clock, and another cocked at what is considered to be proper, professional behavior- not rocking the boat, not straying outside the accepted paradigms or limits, making yourself marketable and above all presentable, hence uncontroversial and unpolitical and "objective." (Said, 1994/1996, p. 74)

In this respect, it is possible to connect this issue of independence of the intellectual with Sartre's notion of freedom of choice. In "What is Literature?" And Other Essays, Sartre (1948/1988) claims that man is essentially free to choose his own destiny but a certain situation, an obstacle may prevent a total execution of such freedom. Nevertheless, Sartre adds, it is wrong to say that environment and situation by itself alone determine the writer or intellectual's actions. He argues that there is a continuous movement back and forth between them (p. 77). Sartre uses the word writer rather than intellectual, but it is clear that he is speaking about the role of the intellectual in society, as in the following lines:

I am an author, first of all, by my free intention to write. But at one it follows that I become a man whom other men consider as a writer, that is, who has to respond to a certain demand and who has been invested with a certain social function. Whatever game he may want to play, he must play it on the basis of the 
representation, which others have of him. He may want to modify the character that one attributes to the man of letters (or intellectual) in a given society; but in order to change it; he must first slip into it. Hence, the public intervenes, with its customs, its vision of the world, and its conception of society and of literature within that society. It surrounds the writer, it hems him in, and its imperious or sly demands, its refusals and its flights, are the given facts on whose basis a work can be constructed. (Sartre, 1948/1988, pp. 77-8)

What Sartre tries to emphasize is that the intellectual is not someone who is withdrawn to solitude and whom one should idealize and worship. On the contrary, the intellectual is constantly subject not only to the demands of his or her society but also to quite extensive changes in the status of intellectuals as members of a distinct group in the society. What are these pressures today? asks Said (1994/1996), and what is their relation to what he has been calling professionalism? According to him, specialization is the first of these pressures. The higher one goes in the education system today, he claims, the more one is restricted to a comparatively thin zone of knowledge. Specialization, Said (1994/1996) argues, then, may lead to turning a blind eye to other areas and cause a disadvantage for the intellectual to assess his/her subjects poorly.

For instance, in the study of literature, which is his particular area of interest, he believes that there is growing technical formalism and less and less of "a historical sense of what real experiences actually went into the making of a work of literature" (Said, 1994/1996, p. 76). Specialization, as in this example, means losing sight of the raw effort of constructing either art or knowledge; and he claims that as a result one cannot view knowledge and art as choices and decisions, commitments and alignments, but only in terms of impersonal theories or methodologies. Eventually, as a completely specialized literary intellectual one is bound to become tame and accepting of whatever the so-called leaders in the field will allow (Said, 1996). One can witness this in today's academic world. Especially in the way that young scholars, research assistants or graduate students are compelled to refer to certain authorities while writing their papers or dissertations.

Sartre (1948/1988) argues that the existentialist philosophy aims to help the individual to survive or to realize him/herself in the mainstream social aura but tries to do that without separating that individual from the society. Moreover, two of the most important themes of Existentialism are freedom and responsibility. Existentialism can be considered as a philosophy of freedom. The fact that one can stand back from his/her life and consider what he/she has been doing so far lies in its center (Flynn, 2006). In this respect, people are always, Thomas Flynn (2006) argues, more than themselves. However, they are also as responsible as they are free. These are important themes that the existentialists dwell upon.

In A Companion to Phenomenology and Existentialism, Wrathall and Dreyfuss (2006) suggest that existentialism as a movement starts its study with the existing individual, that is the individual involved in a specific world with a distinctive form of life. Therefore, a stress on the body and on the emotional rather than rational side of human beings are representatives of existentialism. For existentialist philosophers, they argue, the focus is on discovering what is exclusive to that individual, rather than treating him/her as a display of a general type. With their focus on the individual and a rejection of any meaningful sense of what creates an essential or absolute goal for human existence, existentialists emphasize human freedom and responsibility, and consider that the only goal consistent with that freedom and 
responsibility is to live authentically (Wrathall and Dreyfuss, 2006). Lastly, existentialists tend to share a disapproval of rationalism and empiricism alike, and often define themselves by their opposition to the main currents of modern philosophy (Wrathall and Dreyfuss, 2006). On the other hand, what does one experience when he/she embraces these thoughts but fails to realize the goal, that is constitution of the self and being an independent individual? A psychological trauma or a crisis, most likely.

Existential crisis, in this sense, is experienced when one is not sure of his/ her aim in life and whether he/she is in control of things or not. This situation occurs, especially in intellectual people, when knowledge and experience do not seem to help for solving a person's frustration, misery or other problems. When Mary Shelley's (1818/1994) Monster said; "Sorrow only increased with knowledge" (p. 116), he was indirectly referring to a kind of existential crisis that today's modern intellectuals are likely to have. The increased awareness of one's self and one's path in life and sometimes overthinking of the possible future problems that are likely to occur, again, cause one to have these sorts of crises. Thus, it would not be surprising to witness this situation in campus novels, where, almost on a daily basis, the characters discuss among themselves or by themselves alone the meaning of life, their function in the society and other philosophical, psychological or religious, rather grand issues. In the light of these observations on the existentialist thought, it is time to exemplify similar features in Changing Places.

\section{Conclusion}

In this respect, can one say that Morris Zapp and Philip Swallow are intellectuals? To which category of intellectuals can one place them according to Gramsci's, Said's or Sartre's classifications? Furthermore, do these characters experience any existential crisis? Considering the existentialist standpoint, do they have freedom and control over their lives and are they able to realize their true existences?

Morris Zapp, to start with, as an academic, is an intellectual character. According to Gramsci's views, Zapp is a traditional intellectual who, works and produces in a restricted area, an institution, and uses conventional educational resources, like books, articles and class teaching, in order to convey information. Again, he can also be called a universal intellectual in Foucault's words for being a university professor. Besides, he is also appropriate for Edward Said's understanding of the model intellectual who is supposed to help and enlighten the public. This is evident especially for the way Zapp got involved with student protests in Rummidge and built a bridge between the students and the administration, making a difference that no other faculty at Rummidge dared to. Even though Zapp is depicted as manipulative and aggressive for most of the times, he can control his professional life and achieve many of his professional goals. He actively alters the lives of other people and is able to become, to some of them, an example figure. The fact that he cannot save his marriage may probably be a price he has to pay for being professionally successful.

There are times when Zapp questions his destination in life, especially when he realizes that he has progressed so much and so fast in the academic ladder and there is not much left to achieve in his field. Embarking on an impossible project, that is writing a critical book that would cover criticism of every novel of Jane Austen, from every possible angle, so that nothing else would be left to say on the subject, was his way of coping with his existential 
crisis. Failing in this, he chooses to join the exchange program and goes to Rummidge for getting away from his problems for a while and spend some time by himself. Strangely, the dull seeming British city and the university provides him with means to cope with his existential crisis. By engaging with the student protests and successfully creating a peaceful resolution, he gets a grip on himself once again and finds meaning in life. He is offered a permanent position by the university administration and the chairmanship of the department. Moreover, what should be taken into consideration is that he does all these things while still remaining a radical man who does not live according to the conventional rules of the society. This shows that he can become himself and achieve by his rules, and is able to execute a kind of freedom that is proposed by Sartre as every man should execute. Following his own route in life, Zapp seems to have reached an ideal human level addressed by Sartre and Existentialism.

Can the similar things be said about Philip Swallow? Probably not. Although he may not have the appropriate function of an intellectual in society, Philip Swallow can be considered as an intellectual. In accordance with Gramsci's and Foucault's arguments, as a reader, instructor and a thinker, he is an intellectual. As Lodge declares that he wrote Changing Places out of his own experiences when he travelled to America as an exchange scholar, it is clear that Philip Swallow's character originated from Lodge himself. Swallow's nervousness and existential crisis were also those of the author which were revealed in the novel. It is stated in the novel that Swallow likes literature of all kinds but lacks a field of his own (Lodge, 1975/1978). Further explained in the novel as:

Philip Swallow was a man with a genuine love of literature in all its diverse forms. He was as happy with Beowulf as with Virginia Woolf, with Waiting for Godot as with Gammer Gurton's Needle, and in odd moments when nobler examples of the written word were not to hand he read attentively the backs of cornflakes packets, the small print on railway tickets and the advertising matter in books of stamps. This undiscriminating enthusiasm, however, prevented him from settling on a 'field' to cultivate as his own ... He ran hither and thither between the shelves of Eng. Lit. like a child in a toyshop- so reluctant to choose one item to the exclusion of others that he ended up empty-handed. (Lodge, 1975/1978, p. 17)

Being fieldless is, in fact, not a negative feature for an intellectual according to Edward Said. However, Swallow also lacks the courage and confidence to make a move, write a book or attempt to change society in any way. He is always "anxious to please, anxious not to offend" (Lodge, 1975/1978, p. 180). Although, like Zapp, he joins some of the student protests in Euphoria, in the end, he feels he does not belong to these kind of activities and seeks shelter in running back to his old life from which he was so eager to detach himself from. Swallow's resistance to and fear of change is also revealed in one of his wife's comments on him. When Morris Zapp says he is curious to know why there are a hundred and fifty-seven tobacco cans in a cupboard in Swallow's office and asks if he collects such things, Hilary says: “Oh, I don't suppose he collects them. I expect he just can't bear to throw them away. He's like that with things" (Lodge, 1975/1978, p. 86). Also, it is Philip's second journey to the United States after ten years. He remembers the last time he was there and it is explained in the novel as: "emotionally it is still for him a kind of Paradise, the place where he was once happy and free and may be so once again" (p. 21). Thus, he wants to be free, like Sartre says one should be, but he cannot accomplish this goal because he thinks it is too late for him. 
In conclusion, relating to the author's observations in 1969, Changing Places reflects a vivid and a genuine picture of the campus life of the time, together with the cities they are situated in, the student protests, the academic competition and all other aspects. Morris Zapp and Philip Swallow, the main characters of the novel are portrayed as opposite characters, having different attitudes towards life and academy. Both characters experience existential crisis and try to cope with it. However, while Zapp successfully defeats his own, Swallow shows an escapist tendency and follows the safe lane, by saying, with a reference to W.B. Yeats' "Sailing to Byzantium" (1928), that "that is no country for old men" (Lodge, 1975/1978, p. 249). Finally, when read and analyzed from an existentialist point of view, Changing Places displays how two contemporary intellectuals cope with their existential crises in a realistically portrayed academic world and their personal transformations in the process.

\section{References}

Anténe, P. (2015) Campus novel variations: A comparative study of an Anglo-

American genre. (Doctoral dissertation, Palacký University, Olomouc, Czech Republic).

Retrieved from https://theses.cz/id/6wpr47/Dissertation_Antne.pdf

Falk, W. W. and S. Molloy (1985). Changing places revisited: The

'cosmopolitan motif' brought to life. Teaching Sociology, 12(4), 379-395.

Flynn, T. (2006). Existentialism: A very short introduction. NYC, NY: Oxford UP.

Foucault, M. (1980). Power/knowledge: Selected interviews and other writings 1972-

1977. Colin Gordon (Ed.), (Colin Gordon, et al. Trans.). NYC, NY: Pantheon.

Friji, N. (2019). The cultural revolution in David Lodge's changing places. Arab

World English Journal for Translation E Literary Studies, 3(2), 22-36.

DOI: http://dx.doi.org/10.24093/awejtls/vol3no2.3.

Gramsci, A. (1992). The prison notebooks: Selections (Quintin Hoare and Geoffrey

Nowell-Smith, Trans.). NYC, NY: International Publishers. (Original work published 1947)

Lodge, D. (1978). Changing places: A tale of two campuses. London, UK: Penguin. (Original work published 1975)

Lodge, D. (1996). Fact and fiction in the novel: An author's note, The Practice of Writing (pp. 20-39) London, UK: Penguin.

Martin, B. A. (2000). David Lodge's changing places: The paradoxes of a liberal metahctionist. EPOS, 16, 293-302.

Perkin, J. R. (2008). The pilgrimages of David Lodge. Christianity and Literature, 57(3), 419-442.

Said, E. (1996). Representations of the Intellectual. NYC, NY: Vintage. (Original work published 1994)

Sartre, J. P. (1965). Essays in Existentialism. Wade Baskin (Ed.). Secaucus, NJ: The Citadel 
Press.

Sartre, J. P. (1978). Being and Nothingness: A Phenomenological Essay on Ontology (Hazel E. Barnes, Trans.). NYC, NY: Pocket Books. (Original work published 1943)

Sartre, J. P. (1988). What is Literature? And Other Essays. (Bernard Frechtman, Trans.). Cambridge, MA: Harvard UP. (Original work published 1948)

Shattock, M. (1984). British higher education under pressure: Politics, budgets and demography and the acceleration of ideas for change. European Journal of Education, 19(2), 201-216.

Shelley, M. (1994). Frankenstein. London, UK: Penguin. (Original work published 1818)

Stevens, P. (2002). Pretending to be real: Stephen Greenblatt and the legacy of popular existentialism. New Literary History, 33(3), 491-519.

Wrathall, M. A. and H. L., Dreyfus (2006). A brief introduction to phenomenology and existentialism. In Wrathall, M. A. and H. L., Dreyfus (Eds.), A Companion to Phenomenology and Existentialism (pp. 1-7). Malden, MA: Blackwell. 